\title{
TROPHIC AND NUTRIENT DYNAMIC ASPECT OF AQUATIC MICROBIAL ECOLOGY
}

\author{
Tek Bahadur Gurung ${ }^{1 *}$ and Jotaro Urabe ${ }^{2}$ \\ ${ }^{1}$ Fisheries Research Division, Godawari, Lalitpur, Nepal \\ ${ }^{2}$ Tohoku University, School of Life Sciences, Biological buildings, Aoba, Sendai 980-8578, Japan \\ *E-mail: tek_fisheries@hotmail.com
}

\begin{abstract}
This paper gives a chronological review on our understanding in the role of heterotrophic bacteria in trophic and nutrient dynamic aspects of aquatic microbial ecology. Traditionally, the role of heterotrophic bacteria was known as decomposer only. Later studies revealed that bacteria could be the food for several grazers especially, nano-, micro- and mesozooplankton. Now, it is clear that heterotrophic bacteria channel the energy and matter to higher trophic level via microbial and metazoan food chains. Previously it was argued that dissolved organic carbon (DOC) is the prime limiting factor for fueling the energy and nutrient in aquatic ecosystem. However, emerging experimental evidences suggest that enrichment of plant nutrients such as phosphorus $(\mathrm{P})$ stimulates bacterial growth. These suggest accumulation or organic carbon and other important nutrients in aquatic ecosystem, which are funneled in presence of limiting nutrients phosphorus. Moreover, recent studies showed that material transfer efficiency from bacteria to higher trophic level may depend on species composition of mesozooplankton. These discoveries established that bacterial primary production contributes substantially in secondary production, implying that contrasting to their tiny form bacteria play much important role in trophic and nutrient dynamics aspects of aquatic ecology.
\end{abstract}

Key words: Heterotrophic bacteria, trophic dynamics, nutrients, mesozooplankton.

\section{INTRODUCTION}

Heterotrophic bacterio-plankton, one of the minute prokaryotic organisms ranging approximately from 0.2 to $2.0 \mu \mathrm{m}$ has been the key studies in trophic and nutrient dynamic aspects of aquatic microbial ecology. These miniatures play important role in biogeochemical cycling through decomposition and being food particle for micro and metazoan grazers in aquatic environment (Azam et al. 1983, Cotner and Biddanda 2002, Burns and Galbraith 2007). Previously, the role of bacteria was known as decomposer and mineralizer only (Lindeman 1941). However, later it was revealed that bacteria consume dissolved organic carbon (DOC) and nutrients (Pomeroy 1974, Azam et al. 1983) supplied through endogenous and exogenous sources, and become food for micro and metazoan grazers (Fenchel 1982, Pace et al. 2004, Urabe et al. 2005).

The abundance of bacteria vary according to trophic status of the water bodies, varying from 0.5 to $1 \times 10^{6}$ cells $\mathrm{mL}^{-1}$ in oligotrophic systems to 10 $\times 10^{6}$ cells $\mathrm{mL}^{-1}$ in eutrophic system (Cotner and Biddanda 2002). Each bacterium is assumed to 
contain 20-30 fg carbon (C) (Lee and Fuhrman 1987), this means $10^{-5}$ to $10^{-4} \mathrm{~g} \mathrm{C} \mathrm{L} \mathrm{L}^{-1}$. Thus, this value indicates that bacterial biomass represents substantial fraction of planktonic biomass in aquatic ecosystems (Gurung et al. 2002).

Bacteria have been recently categorized as aquatic plankton after recognizing that they play important role in secondary production via bacterial primary production. For energy and material cycling bacteria have been emphasized much because of their abundance and per unit higher surface-volume ratio (Li et al. 2004). The knowledge on bacteria is integral for understanding biological, geological and chemical complexity of the biosphere. Therefore, this paper aims to give an introductory chronological review on the role of bacteria in trophic and nutrient dynamic aspect of aquatic microbial ecology.

\section{Evolutionary trend of trophic and nutrient dynamics}

Energy and material cycling in aquatic environment is one of the fundamental and enticing sciences of ecology. In the beginning of $20^{\text {th }}$ century, Thienmann (1926) showed that matter and energy in aquatic environment channel from autotroph to heterotroph (Fig. 1), but bacteria were not referred in his paradigm. Lindeman (1942) in his classic work did not assign any trophic level to bacteria, but were considered as decomposers, supplying inorganic nutrients to primary producers (Fig. 2). Later works showed that most bacteria largely consume dissolved organic matter (DOM) for their growth and production (Wright and Hobbie 1966). Supporting this view that bacteria highly depend on organic carbon produced by autotroph, cross system studies demonstrated that bacterial abundance in aquatic ecosystems correspond to phytoplankton density and chlorophyll $a$ concentration (Bird and Kalff 1984, Cole et al. 1988, Li et al. 2004). Bacterial production and/or biomass covary with primary production or phytoplankton biomass over aquatic systems (Pace et al. 2004). These studies showed that bacteria use dissolved organic carbon (DOC) originated from phytoplankton as an energy source (Wright and Hobbie 1966, Coveney 1982).

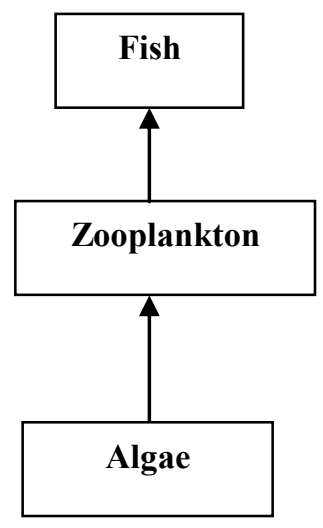

Fig. 1. Simple tradition view of aquatic ecosystem proposed by Thienmann (1926).

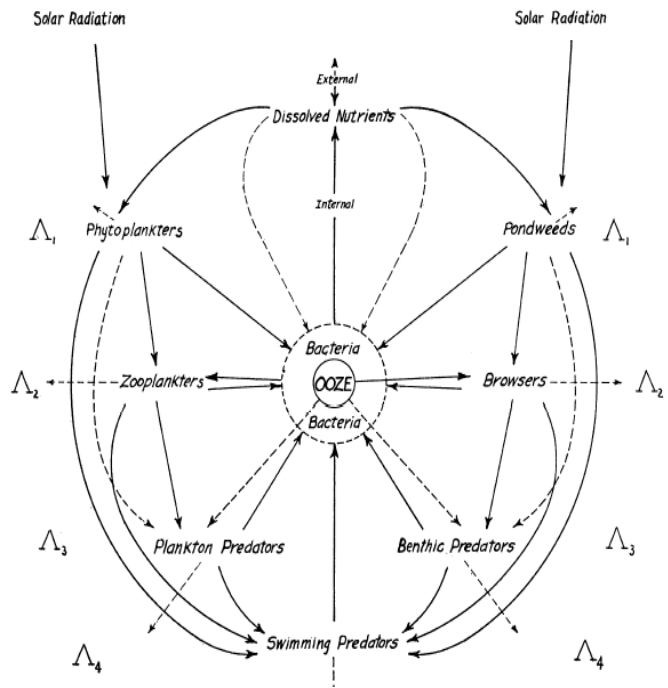

Fig. 2. Lindman's (1942) conceptual model on aquatic food web.

With recognizing the importance of energy resources for bacteria, many studies focused on the relationship between phytoplankton and bacteria in aquatic environment (Bratbak and Thingstad 
1985). However, studies involving enrichment experiments with organic and inorganic chemicals have demonstrated that bacterial growth is also limited by inorganic nutrients (Toolan et al. 1991, Coveney and Wetzel 1995, Gurung and Urabe 1999). Since important nutrients limit phytoplankton growth, the relationship between bacteria and phytoplankton might be regarded as competitive. At low nutrient concentration, phytoplankton can stimulate the growth of their potential competitor, because bacteria have a high affinity for low nutrient concentration (Currie and Kalff 1984). However, when nutrient are in higher concentration phytoplankton are known to uptake more efficiently. These implying that the relationship between bacteria and phytoplankton may not be simple but changes from competitive to commensalisms depending on various environmental conditions (Gurung et al. 1999, Meyer 2000).

Further discoveries (Pomeroy 1974, Pernthalor 2005) showed that bacteria could constitute an important food resource, and provide a resource linkage to metazoan through bacterial primary production. These findings enriched our understanding about the function and dynamics of heterotrophic bacteria. Azam et al. (1983) described that besides the pathway of energy and material flow through classical food chain (phytoplankton $\rightarrow$ zooplankton $\rightarrow$ fish), matter also channel through microbial food chain (dissolved organic matter from phytoplankton $\rightarrow$ bacteria $\rightarrow$ protozoa $\rightarrow$ metazoa). Furthermore, dissolved organic matter produced during the funneling of particulate forms towards the higher trophic level in larger organism also reincorporated in the system again through bacteria. Thus, in new paradigm, bacteria not only function as decomposers, but also "link" the energy and matters towards the higher trophic level (Fig. 3). This concept of channeling the energy and matter by bacteria was indeed a "paradigm shift" in our understanding in microbial ecological science.

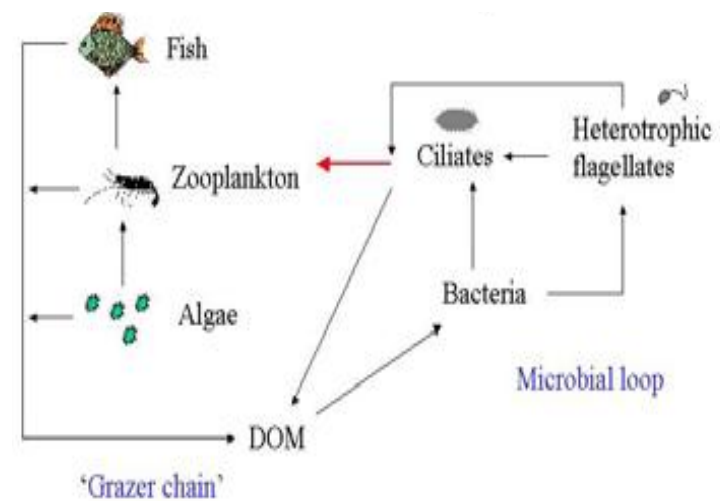

Fig. 3. Interrelationship between microbial loop and grazer chain.

\section{Recent views on trophic and nutrient dynamics aspect of aquatic microbiology}

Bacteria constitute an important food resource especially for protozoan, rotifer, and crustacean (Fenchel 1982, Sherr and Sherr 2001, Yoshida et al. 2001). The growth rate of bacteria is known to be one of the fastest among unicellular organism, if suitable conditions prevail. Despite of such characteristics, however, in natural ecosystem, mostly the bacterial abundance does not vary drastically but remain stable within a limited magnitude in a given ecosystem (Güde 1986, Gurung et al. 2001). The higher grazing rate by microbial grazers implies the substantial role of material flux by bacterial production. Both laboratory and field studies have shown the grazing as well as resource supplies are important factors determining bacterial dynamics in aquatic ecosystems (Elser et al. 1995, Burns and Galbraith 2007). These facts also suggest that bacteria can compensate their grazing loss by rapid growth. For example, grazer may affect bacteria positively by alerting the resource condition. It is known that prey and predator relations are not only exploitive, but also affect the prey organisms positively by 
alerting the resource condition (Gurung et al. 2000, Kagami et al. 2002).

Earlier the bacterial abundance was known to be yielded by dissolved organic matter (DOM) and consumed by grazers like heterotrophic nanoflagellates (HNF) (Fig. 4A). The HNF, in turn are grazed by micro and meso-zooplankton (Gurung 2000, Pernthalor 2005). According to this view, bacterial growth is increased with increase in DOC supply. However, recent studies provided evidences that bacterial growth is also increased by addition of nutrients (Fig 4B). In recent studies, evidences have been mounted to demonstrate bacterial growth limitation by inorganic phosphorus not only in freshwaters but also coastal and diverse parts of oceans (Rivkin and Anderson 1991, Thingstad et al. 2005). Earlier it was regarded that substrate or organic carbon constrained bacterial growth (Kjellberg et al. 1993). However, limitation of phosphorus for bacterial growth has been demonstrated in lakes (Toolan et al. 1991, Sterner et al. 2004), river (Farzalla et al. 2002, Castillo et al. 2003), estuaries (Findlay et al. 1991), coastal waters (Thingstad et al. 1998, 2005) and ocean (Zohary et al. 1993, Rivkin and Anderson 1997, Flaten et al. 2005). These results demonstrating that addition of phosphorus may fuel the use of organic carbon from aquatic ecosystem via bacterial growth and production.

Recent studies showed that bacterial growth is not increased with DOC, because of nutrient limitation (Fig. 4B). These suggest that in ambient water probably DOC might be sufficient relative to the demand specifically in fresh and coastal water due to external supply in addition to internal input. As a result, bacterial growth and abundance may not necessary coupled with phytoplankton production and abundance (Findlay et al. 1991, Robarts et al. 1994). These findings suggest that traditional view point that only addition of organic carbon regulates the bacterial abundance should be modified.

Grazers can affect bacterial abundance not only negatively but also positively by releasing nutrients (Fig. 4C), they can indirectly stimulate bacterial growth rate. Thus, nutrient release from grazers plays a crucial role in regulating bacterial abundance. In several studies (Gurung et al. 2001, Yoshida et al. 2001) it has been shown that, some metazoans such as Daphnia affect bacterial abundance negatively, as Daphnia can ingest bacteria (Fig. 4D), contrastingly, E. japonicus can stimulate bacterial abundance by decreasing bacterial grazers without ingesting bacteria (Fig. 4E). This fact suggests that material transfer efficiency from bacteria to higher trophic levels depend on species composition of metazoans (Figs. 4D and E). When E. japonicus is dominated, however, bacteria may act as 'sink' because this metazoan cannot utilize bacteria but reduce bacterivore protozoan. These findings are in line with several other studies (Burns and Schallenberg 1996) showing indeed, cladoceran and calanoid crustaceans impact over bacterial dynamics in aquatic ecosystem. These evidences suggest that the knowledge of trophic and nutrient aspects of microbial ecology would be essential to understand the biogeochemistry and complexity of the biosphere.

The marine microbiology is considered to be relatively well developed (Meyer 2000), however, knowledge on aquatic microbial ecology from fresh water systems especially from high altitude regions may provide new insights on our understandings of terrestrial-aquatic environments interactions. This knowledge would be important to understand catchments use pattern, global biogeochemistry and biocomplexity. 


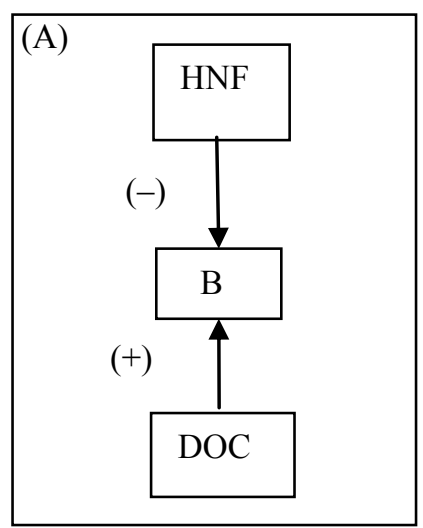

(B)

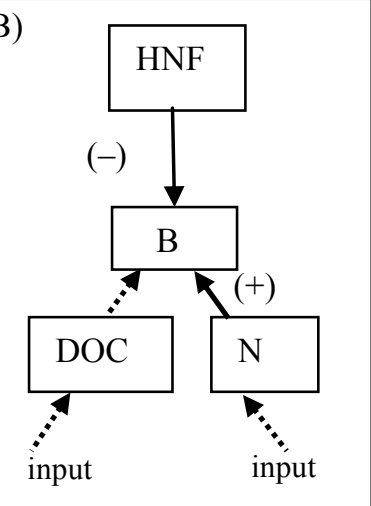

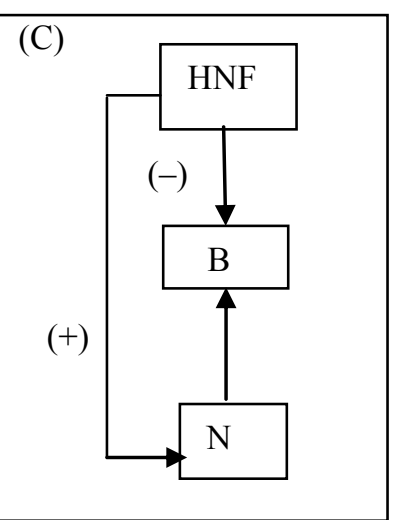
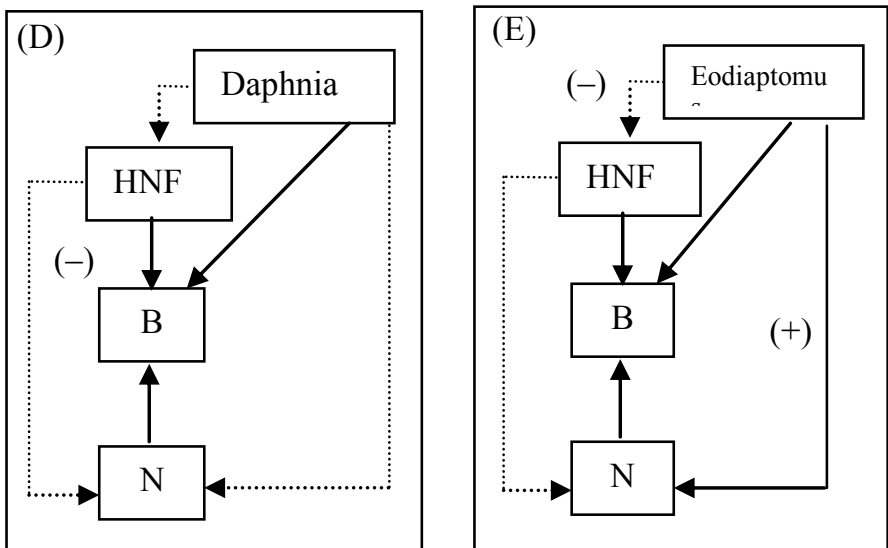

Figs. 4 (A-E). Simplified sketch showing dominant factors regulating bacterial abundance in aquatic environment: the dotted line indicates possible but less important factors. The symbols of plus and minus indicate positive and negative effects of each component on bacterial abundance. B, Bacteria, N: nutrients, HNF: heterotrophic nanoflagellates (based on Gurung 2000).

\section{ACKNOWLEDGEMENTS}

Sincere thanks to all of the staffs of Fisheries Research Division, Godawari for their kind support during the preparation of this paper. Partly the fund for this work was supported by US Education Foundation. Comments from the participants during the meeting of Ecological Society of Nepal have helped to improve the manuscript.

\section{REFERENCES}

Azam, F., T. Fenchel, J.G. Field, J.S. Gray, L.A. Meyer-Reil and F. Thingstad. 1983. The ecological role of microbes in the sea. Marine Ecol. Prog. Ser. 10:257-263.

Bird, D.F. and J. Kalff. 1984. Empirical relationship between bacterial abundance and chlorophyll concentration in fresh and marine waters. Can. J. Fish. Aqu. Sci. 41:1015-1023. 
Bratbak, G. and T.F. Thingstad. 1985. Phytoplankton-bacteria interactions: an apparent paradox? Analysis of a model system with both competition and commensalism. Marine Ecol. Prog. Ser. 25:23-30.

Burns, C.W. and L.M. Galbraith. 2007. Relating planktonic microbial food web structure in lentic freshwater ecosystems to water quality and land use. J. Plankt. Res. 29:127-139.

Burns, C.W. and M. Schallenberg. 1996. Relative impacts of copepods, cladocerans and nutrients on the microbial food web of a mesotrophic lake. J. Plankt. Res. 18:683-714.

Castillo, M.M., G.W. Kling and J.D. Allan. 2003. Bottom-up controls on bacterial production in tropical lowland rivers. Limnol. Oceanog. 48:1466-1475.

Cole, J.J., S. Findlay and M.L. Pace. 1988. Bacterial production in fresh and saltwater ecosyetms: a cross-system over view. Marine Ecol. Prog. Ser. 43:1-10.

Cotner, J.B. and B.A. Biddanda. 2002. Small players, large role: microbial influence on biogeochemical processes in pelagic aquatic ecosystem. Ecosystems 5:105-121.

Coveney, M.F. 1982. Bacterial uptake of photosynthetic carbon from freshwater phytoplankton. Oikos 38:8-20.

Coveney, M.F. and R.G. Wetzel. 1995. Biomass, production, and specific growth rate of bacterioplankton and coupling to phytoplankton in an oligotrophic lake. Limnol. Oceanog. 40:1187-1200.

Currie, D.J. and J. Kalff. 1984. The relative importance of the abilities of freshwater algae and phytoplankton in phosphorus uptake in freshwater. Limnol. Oceanog. 29:298-310.
Elser, J.J., L.B. Stabler and R.P. Hasset. 1995. Nutrient limitation of bacterial growth and rates of bacteriovory in lakes and oceans: a comparative study. Aqua. Microb. Ecol. 9:105110 .

Farjalla, V.F., A.E. Francisco, R.L. Bozelli and R. Fabio. 2002. Nutrient limitation of bacterial production in clear water Amazonian ecosystems. Hydrobiologia 489:197-205.

Fenchel, T. 1982. Ecology of heterotrophic micro flagellates: quantitative occurrence and importance as bacterial consumers. Marine Ecol. Prog. Ser. 8:35-42.

Findlay, S., M.L. Pace, D. Lints and J.J. Cole. 1991. Weak coupling of bacterial and algal production in a heterotrophic ecosystem: the Hudson River estuary. Limnol. Oceanog. 36:268-278.

Flaten, G.A.F., E.F. Skjoldal, M.D. Krom, S.L. Cliff, R.F.C. Mantoura, P. Paraskevi, S. Psarra, T. Tanaka, A. Tselepides, E.M.S. Woodward, T. Zohary and T.F. Thingstad. 2005. Studies of the microbial P-cycle during a Lagrangian phosphate-addition experiment in the Eastern Mediterranean. Deep-Sea Research 52:29282943.

Gude, H. 1986. Loss processes influencing growth of planktonic bacterial production in Lake Constance. J. Plankt. Res. 8:795-810.

Gurung, T.B. 2000. Function and dynamics of heterotrophic bacteria in Lake Biwa, Japan. Ph.D. dissertation submitted to Kyoto University, Japan, 58 pp.

Gurung, T.B. and J. Urabe. 1999. Temporal and vertical differences in factors limiting growth rate of heterotroprohc bacteria in Lake Biwa. Microb. Ecol. 38:136-145. 
Gurung, T.B., J. Urabe, K. Nozaki, Y. Yoshimizu and M. Nakanishi. 2002. Bacterioplankton production in a water column of Lake Biwa. Lakes and Reservoirs: Res. Manag. 7:317-323.

Gurung, T.B., M. Kagami, T. Yoshida and J. Urabe. 2001. Relative importance of biotic and abiotic factors affecting bacterial abundance in Lake Biwa: an empirical analysis. Limnology 2:19-28.

Gurung, T.B., M. Nakanishi and J. Urabe. 1999. Regulation of the relationship between phytoplankton Scenedesmus acutus and heterotrophic bacteria by the balance of light and nutrients. Aqua. Microb. Ecol. 17:27-35.

Gurung, T.B., M. Nakanishi and J. Urabe. 2000. Seasonal and vertical differences in negative and positive effects of grazers on heterotrophic bacteria in Lake Biwa. Limnol. Oceanog. 8:1689-1696.

Kagami, M., T. Yoshida, T.B. Gurung and J. Urabe. 2002. Direct and indirect effects of zooplankton on algal composition in in situ grazing experiments. Oecologia 133:356-363.

Kjelleberg, S., K.B.G. Flärdh, T. Nystrom and D.J.W. Moriarty. 1993. Growth limitation and starvation of bacteria. In: Aquatic Microbiology. (ed.) Timothy E Ford. Blackwell Scientific Publication. pp 289-321.

Le, J., J.D. Wehr and L. Campbell. 1994. Uncoupling of bacterioplankton and phytoplankton production on fresh waters is affected by inorganic nutrient limitation. Appl. Environ. Microbiol. 60:2086-2093.

Lee, S. and J.D. Fuhrman. 1987. Relationship between biovolume and biomass of naturally derived marine bacterioplankton. Appl. Environ. Micribiol. 53:1298-1303.
Li, W.K.W., J.H.H. Erica and W.G. Harrison. 2004. Macroecological limits of heterotrophic bacterial abundance in the ocean. Deep-Sea Research 51:1529-1540.

Lindeman, R.L. 1942. The trophic-dynamic aspects of ecology. Ecology 23:399-417.

Meyer, S.P. 2000. Developments in aquatic microbiology. International Microbiol. 3:203211.

Pace, M.L., J.J. Cole, S.R. Carpenter, J.F. Kitchell, J.R. Hodgson, M.C. Van de Bogert1, D.L. Bade, E.S. Kritzberg and B. David. 2004. Whole lake carbon-13 additions reveal terrestrial support of aquatic food webs. Nature 427:240-243

Pernthalor, J. 2005. Predation on prokaryotes in the water column and its ecological implication. Nat. Rev. Microbiol. 3:537-546.

Pomeroy, L.R. 1974. The ocean's food web, a changing paradigm. BioScience 24:499-504.

Rivkin, R.B. and M.R. Anderson. 1997. Inorganic nutrient limitation of oceanic bacterioplankton. Limnol. Oceanog. 42:730-740.

Robarts, R.D., M.T. Arts, M.S. Evans and M.J. Waiser. 1994. The coupling of heterotrophic bacterial and phytoplankton production in a hypereutrophic, shallow lake. Can. J. Fish. Aqua. Sci. 51:2219-2226.

Sherr, E. and B. Sherr 2001. Role of microbes in pelagic food webs: A revised concept. Aqua. Microb. Ecol. 25:195-206.

Sterner, R.W., T.M. Smuutka, R.M.L. Mckay, Q. Xiaomong, E.T. Brown and R.M. Sherrell. 2004. Phosphorus and trace metal limitation of algae and bacteria in Lake Superior. Limnol. Oceanog. 49:495-507. 
Thienmann, A. 1926 Der Nahrungskreislauf im Waser. Verh deutsch Zool. Ges. 31:29-79.

Thingstad, T.F., M.D. Krom, R.F.C. Mantoura, G.A.F. Flaten, S. Groom, B. Herut, N. Kress, C.S. Law, A. Pasternak, P. Pitta, S. Psarra, F. Rassoulzadegan, T. Tanaka, A. Tselepides, P. Wassmann, E.M.S. Woodward, C.W. Riser, G. Zodiatis and T. Zohary. 2005. Nature of phosphorus limitation in the ultraoligotrophic Eastern Mediterranean. Science 309:10681071.

Thingstad, T.F., U.L. Zweifel and F. Rassoulzadegan. 1998. P limitation of heterotrophic bacteria and phytoplankton in the northwestern Mediterranean. Limnol. Oceanog. 43:88-94.

Toolan, T., J.D. Wehr and S. Findlay. 1991. Inorganic phosphorus stimulation of bacterioplankton production in a mesoeutrophic lake. Appl. Environ. Microbiol. 57:2074-2078.
Urabe J., T. Yoshida, T.B. Gurung, T. Sekino, N. Tsugeki, K. Nozaki, M. Maruo, E. Nakayama and M. Nakanishi. 2005. The production-torespiration ratio and its implication in Lake Biwa, Japan. Ecol. Res. 20:367-375.

Wright, R.T. and J.E. Hobbie. 1966. Use of glucose and acetate by bacteria and algae in aquatic ecosystem. Ecology 47:447-464.

Yoshida, T., T.B. Gurung, M. Kagami and J. Urabe. 2001. Contrasting effects of a cladoceran (Daphnia galeata) and a calanoid copepods (Eodiaptomus japonicus) on algal and microbial plankton in a Japanese Lake, Lake Biwa. Oecologia 129:602-610.

Zohary, T., B. Herutb, M.D. Krom, R.F.C. Mantourad, P. Pittae, S. Psarrae, F. Rassoulzadegan, N. Stamblerg, T. Tanaka, T.F. Thingstad and E.M.S. Woodwardi 2005. Plimited bacteria but $\mathrm{N}$ and $\mathrm{P}$ co-limited phytoplankton in the Eastern Mediterranean - a microcosm experiment. Deep-Sea Research II, 52:3011-302. 